\title{
Morphological Untits of Golloborda's Highland in the Republic of Albania
}

\author{
Elvira Bollobani - Dodoveci, Candidate PhD
}

Doi:10.5901/jesr.2014.v4n4p378

Email: elvirabollobani@hotmail.com

\begin{abstract}
Golloborda's highland together with two other highlands which are: Çermenika's highlands which lies in its west and Martanesh highland which lies in northwest of Golloborda which occupy the central part of central highland province unlike two other highlands. That of Golloborda lies in the east of our country and continues even outside the state border in Macedonia. The study object of this work paper are the morphological particularities of the units of Golloborda highlands which lie inside the physical - geographical space of the Republic of Albania. Initially, are given some physical - geographical dates of the highland of Golloborda. Then it goes through morphological analysis of its components. As a result of diverse litologic construction, geologic structures, complicated reliev evolution of its area under over complicated influence and external factors, I have determined these morphological units: the field of Klenja, the field of Stude, the trough of Llanga, the trough of Okshtun and the mountain ridge of Veternik - Kallkan. The aim of this paper is that these units should be analysed highlighting morphological and morphogenic feature. To realize this paper, I have exploited the written literature of this area, consultations with specialized people of this field, even other similar work papers. This article will serve to different amateurs and also to specialized people of the geography field. This work paper will be conluded in base of some conclusions.
\end{abstract}

Keywords: Golloborda, highland, morphological unit, karst area.

\section{Introduction}

It lies in the east of our country. According to geographic aspect, it lies between the highland of Martanesh in north west, where as a natural border serves the middle part of Zall valley of Okshtun, in west and south-west it is divided from valley of Llanga stream by the highland of Çermenika. In the eastern part, the border state of the Republic of Albania with that of Macedonia, serves even as a natural border. Within these borders, Golloborda's area has a surface of about 300 $\mathrm{km}^{2}$. The area looks like an armchair, with a view toward east. Eastern borders even those western are expressed with morphological contrasts, evidence of differential neotectonic movements. This highland is part of the tectonic area of Mirdita and partially at Saint George corridor, of the tectonic area of Krasta - Cukal ${ }^{1}$. In the geologic contruction are included trias - jurasik limestones, extremely chopped from the tectonic, which form generations with a south - west direction north - east and west - east even old terrigene generation.

In north - west by phlysh of the Saint George corridor. In its geologic composition dominate limestones to which are connected the wide diffusions of the karstic shapes whilst other deposits like phlysches, conglomerates, even those of quaternary have a limited diffusion, mainly in fluid form (Stude, Klenje, Gjinovec) (Krutaj, 2006). By its structural edge deposits of Golloborda units form the anticline of Klenja which is dislocated in south east direction of the Okshtun anticline and Studa syncline. Dissociative demolitions have triggered karst processes in this area. Through the highland of Golloborda passes the regional breakdown Vlore - Lushje - Elbasan - Diber which is active even nowadays, which is observed even by frequent earthquakes. To that are connected tectonic coverings and over climbings structures (Aliaj, 2012).

By the morphogenetic side prevails kartstic relieve with numerous rippling of the reliev, with soft watershed, narrow deep valleys karstic - erosive. Surface leaks are few, in some parts there is a lack of lantern as a result of Krasta diffusion. Karstic forms are developed and are situated next to each - other. Surface karstic forms are gutters, different cavities which are still uncharted (Krutaj, 2006). Depending on the tectonic conditions and morphostructural factors in this highland, there are segregated these morphologic subunits: the mountain rigde of Veternik - Kallkan, trough of Llanga, the field of Klenja, the field of Studa, Okshtun trough, which are going to be treated together.

\footnotetext{
1 Group of Authors. (1983). Geologic map of Albania and the explanatory book Geology of Albania, Tirana
} 


\section{Mountain Ridge Veternik - Kallkan}

Unlike that of Lunik, this mountain ridge is construted almost of phlysch rocks and rarely by limestones of Mesozoic which appear on the top of Veternik even that of Raduc. It lies in a meridional direction toward the border line with Macedonia being entirely involved, as that of the mountain ridge of Lunik in the tectonic area of Mirdita. Natural borders of this mountain ridge are: the field of Studa, Stebleva, Klenja in south - west also the gorge of Black Drin (outside Macedonia border) in north - east, whilst by the south - east it has a continuity with the mountain of Jabllanica and that of Miraka in south - west. General length of this mountain ridge, among Trebisht in north and the top of Kallkan from south, reaches a length of about $24 \mathrm{~km}$, the height rises at a same direction from Veternik top (1441 m) to that of Kallkan (2132 m) characterized by a staggered shape due to a blocked tectonic (Gruda, 1996). The most salient morphologic feature of this mountain ridge is the structural asymmetry. From the north - east of the gorge of the Black Drini determing simultaneously the general shape of a monoclinal ridge. Precisely, the slope of this ridge, so the western slope in our county, is distinguished by many smaller sizes of that from east, but in whole it has an inclination relatively bigger, among the structural scale of Trebisht and the tectonic neck of Raduc $(1519 \mathrm{~m})$, despite the dense development which have given a very degraded shape (Gruda, 1996). The reliev has a less expressed shape due to its relative height of (200 $300 \mathrm{~m}$ ) above the tectonic trough of Trebisht, whilst the increasing height into south direction has directly affected in to the disintegrated values of this slope up to Kallkan top. The sector of this slope among the Raduc neck and Kallkan top with a height of $1600-2100 \mathrm{~m}$ is modelled by glacial quaternary, which is expressed to the reliev with simple circus exactly with these heights. Over to these circus begin the water network of Klenja and Stebleva stream. Phlysch composition of this slope has determined big values of the density of the reliev fragmentation $\left(3-5 \mathrm{~km} / \mathrm{km}^{2}\right)$, whilst the amplitude of the rising of its structures has leaded into average values of reliev fragmentation $\left(200-300 \mathrm{~m} / \mathrm{km}^{2}\right)$. Another morphologic feature of this slope, as that of Veternik - Kallkan mountain ridge, is the staggered shape due to the presence of some blocks of limestones among Klenja and Stebleva with a hight of $1300-1500 \mathrm{~m}$ creating a curved shape with the presence of secondary litological steeps (Gruda, 1996).

With stressed morphological changes is presented the eastern slope in Macedonia, which consist in the back of this ridge with bigger sizes until it ends in the gorge of the Black Drini. The interruption of these slopes has determined, also, the morphological features of the highest part of this mountain ridge, which has got a blocked shape, taking morphological features extremely expressed, similar to those of limited slopes. The first level of the structural scale includes the height $1000-1400 \mathrm{~m}$ which is distinguished by a shape relatively smooth and sliphtly undulate, creating morphological contrasts with limited slopes, especially to that of the west. The principal place of the extension of this structural scale is a clear evidence of the lifting quaternary tectonic role with the dimensions and morphological features of this mountain ridge in the whole (Aliaj, 2012). In continuity the second level involves the height of $1500-1800 \mathrm{~m}$ which creates a contrast expressed with the first level, involving simultaneously the features of a reliev relatively sharper than the mountain ridge in this level. Exactly on this structural scale, as was emphasized above, there are lied glacial circuses, influencing into morphological features of an alpine reliev, especially among Raduc's neck. Naturally, the sharpest form, despite the extension relatively limited, is a characteristic of the third level with a height of $1800-2100 \mathrm{~m}$ in which two pyramid peaks of this ridge are elevated, that of Raduc and Kallkan, creating emphasized changes not only with the two levels mentioned above, but simultaneously even with the limited slopes, especially with that of west.

\section{Trough of Llanga}

Natural borders of the extension of this trough are represented by the mountain ridge of Lunik in north - west up to the tectonic neck of Studa, that of Miraka from south - east till the entrance of the Dragan's gorge, whilts the south - west is widely opened to the valley of the upper stream of the Shkumbin river. The formation of this trough, as it is emphasized above, is done during the tectonic distruction among limestones and Mesozoic phlysch concrete which appears when it ends especially among Llanga and Studa neck (Bollobani, 2013). The presence of this concrete has created conditions for a stream almost permanent due to their penetrability, triggering the fast progress of the repressive erosion of this stream. Morphological activity of this stream is accelerated, also, by the selective character of the erosion which is directly connected with the strength extremely different of the limestones and phlysch toward corrosion, adding simultaneously their dense tectonic distruction (Gruda, 2003). This trough, which at the same time consists on the morphotectonic and morphologic of the limited mountain ridges, has an extension of about $12 \mathrm{~km}$ length, bed slopes about $60 \mathrm{~m} / \mathrm{km}$, partition depth $400-600 \mathrm{~m}$ with a linear extension till Lunik reflecting is tectonic origin, a trough of detached line. The origin of this trough has directly determined even its morphological features which are expressed to emphasize changes of the reliev during its extension. The morphological feature of this trough is its start to the field of 
Studa with the above mentioned dimensions, that's why it looses almost its features up to Llanga, where it is even the ending of this field. Exactly in Llang it narrows immediately, taking the morphological features of a canyon, especially among Llange and Lunik, where appear limestones blocks.

Another morphological phenomena of this trough, is an expressed structural asymmetry of the slopes connected directly to the biggest amplitude of the new tectonic carbonate anticline toward south - west of Lunik, than that of the west of Miraka limitative of this trough of the detached line. Evidence of a tectonic phenomena is also the evasion from north - west of Llanga stream, beginning immediately to the village with the same name until the periclinal clousure of Lunik anticline in south - west. The slopes of this trough have an extension almost the same to the detached line where they are modelled, conserving also the slopes of the above mentioned structures. Among them shows up the right slope of this trough which reaches the height of about $1400-1500 \mathrm{~m}$ which ends up at the bottom of this trough with a slant of $35-50^{\circ}$, of course with characteristic morphologic features is shown the left slope which has got a typical form connected to the concrete phlysch along the western side of Miraka anticline with a height of about $1200-1300 \mathrm{~m}$ segregating the limestone scale among Letmi's field and the immediate twist of this trough toward west. This structural scale ends up also directly at the bottom of this trough with a relative height $250-300 \mathrm{~m}$ and an inclinacion almost the same with that of the right slope (Gruda, 1994). Related to the immediate twist of this trough from the west of Lunik village, we emphasize that it is mainly connected to the periclinal clousure of the anticline with the same name toward south - west with a phlysch size in this sector.

\section{The Field of Klenje and Stude}

A particular morphological importance represent, also the two complex fields in south - east of this mountain ridge, that of Klenja and Stebleva, which are mainly modelled during the contact with an angular dissonance between the limestones and phlysch, being visible on their sizes and morphological features. These morphostructural conditions have simultaneously determined the karst origin and that/of contact, giving them a polygenetic character, which are directly expressed even into their morphological features, especially the irregular form due to the presenze of the water leakage on their phlysch part?

\subsection{The field of Klenja}

It has the form of an irregular quadrilateral with a length of about $2 \mathrm{~km}$ among the Ostren neck in north and the east on the top of about Osoja (1442 m) from south, with approximately east - west until Koritnik neck nearly $1.5 \mathrm{~km}$, whilst the height 1220 - 1300. Its biggest surface is limited by litologic escarpments, which are modelled by the selective erosion between limestones and Mesozoic phlysch, keeping a relative height of about 15. $-200 \mathrm{~m}^{3}$. Similar size presents even that of Stebleva, but it is notable for a very disordered reliev due to the density of the cleavage because of the wide extension of the phlysch and their tectonic contacts mainly with the limestones.

\subsection{The field of Studa}

It lies in the north - east of the mountain ridge of Lunik which has the same origin to that of Klenje, but with a typical longitudinal stretch on the above sector of the trough detached line of Llanga's stream. This morphological feature of this field is connected to such a stretch of the phlysch concrete of Jurasik between carbonatic structures of Lunik in north west and that of Miraka from south - east where resists the coscrele tectonic destruction, provoking the selective erosion of Llanga stream. The length of this field is about $3 \mathrm{~km}$, width $200 \mathrm{~m}$ nearly $1 \mathrm{~km}$ and the height $1137 \mathrm{~m}$ until $1200 \mathrm{~m}$, characterized by a reliev almost flat, especially in its central part (Krutaj, 2006).

It should be emphasized that the expansion of this field is done toward east direction, above the structure of phlysch rocks less sustainable against the corrosion, whilst in west the limestone steep rises immediately up to $500-600$ $\mathrm{m}$ of relative height. Above these conditions of formation this field is presented polygenetic, so modelled by karstogenesis even during the line of detachment, determing such an origin to this field even their complex character, which lie almost along a tectonic detachment of south - east side of Lunik anticline, which simultaneously make the morphotectonic and

\footnotetext{
2 Group of authors (1991). Physic Geography of Albania. Volume II, a publishement of Academy of Sciences PRA, pp. $191-206$, Tirana.

${ }^{3}$ Kote, Dh. \& Vranai, A. "Conglomerate thickness of Klenjë - Studë", in the Bulletin of USHT, a Series of Natural Sciences, No. 1/1965, pp. 111-123, Tirana
} 
morphologic border among the Lunik mountain ridge to that of Veternik - Kallkan from north - east along the border line with Macedonia. A characteristic morphologic phenomena is, also the morphologic contrast $(1400-1600 \mathrm{~m})$ between these fields and two limitative mountain ridges, which are distinguished by visible changes of the height about $(200-600$ $\mathrm{m})$. Of course the decisive phenomena for these morphological contrasts are directly explained with the new tectonics in block, which lead the development of their morphological evolution by selective erosion.

\section{The Okshtun Trough}

The morphological formation and evolution of this trough as it is emphasized above, is done almost entirely during the anticline position of phlysch tectonic "window" almost in the center of that phlysch of Krasta among Prodan and Smollik stream up to the height of $900-1200 \mathrm{~m}^{4}$. Exactly this special characteristic of this trough which lies between structures with completely different composition, simultaneously signs the morphotectonic and morphologic border between the highland of Golloborda in south - east and that of Martanesh in north - west. The general length of this trough between the canyon of Borova in south and the stream at Zalli Bulqizes in the north, reaches about $20 \mathrm{~km}$, whilst the Bed's slope is about $20 \mathrm{~m} / \mathrm{km}$, possessing a big eroted strength, also by the terrigene composition of its majority. Regarding to the structure where it is modelled, in the anticline position of the phlysch rocks of Cretaceous - Paleogene, the trough is not compatible with this position of its structure. The formation of this trough mainly in the north - east of the phlysch anticline, leaving toward south - west a width of about $4 \mathrm{~km}$, is determined by north - east extension of graben pond of Dibra where is involved the water network of Bulqiza's shingle where the Okshtun's stream ends ${ }^{5}$.

One of the morphological features of this trough is its starting with a canyon, as that of Borova, which is created by the stream with the same name, a limestone structure with a length of about $3 \mathrm{~km}$ and a depth of about $300-400 \mathrm{~m}$, creating stressed morphological contrasts with a snaky narrow bed. An important role in the creation of this canyon has played a transverse disconnection of the limestone size which is expressed with the biggest height of the limestone ridge on the top of Zylit $(1518 \mathrm{~m})$ than that of Borova $(1337 \mathrm{~m})$ on its right. The other side of this trough among the canyon estuarine till its wide opening in Bulqiza shingle. Litological composition is simultaneously reflected by morphological features similar to its limited slopes. Whilst the bed of this trough presents unimportant changes of its width fill $20-25 \mathrm{~m}$, despite its dense snaky. The only expansion of this trough is in Lubelesh till $250-300 \mathrm{~m}$, starts by the belt tectonic destruction during a detachment with a length of about $6 \mathrm{~km}$ between the Big Ostren and Lubelesh.

The formation of this trough during the first level of the structural scale $800-1200 \mathrm{~m}$ height is also expressed with the relative increasing of height of the limited slopes simultaneously with the deepening of its bed from $400-500 \mathrm{~m}$ till $500-600 \mathrm{~m}$ specially between Sebisht and Smollik. This trough looses its morphological features with a length of about $4 \mathrm{~km}$ between Lubelesh (Kosovec) and its estuarine which connect the changes almost little visible between the bottom and the shapes with a relative height to it $100-150 \mathrm{~m}$. In Cerenec village ends at Bulqiza shingle where it is opened over a deposit angle, which has a length of about $1 \mathrm{~km}$ and a length of about $500-600 \mathrm{~m}$, influencing the deviation of Bulqiza stream from the left of its flows.

\section{Conlusions}

Golloborda's area has a surface of about $300 \mathrm{~km}^{2}$. This highland is part of the tectonic area of Mirdita and partially at Saint Georgesous corridor of the tectonic area of Krasta - Cukal. Over the geological construction are included limestones of Tria - Jurasik, extremely chopped by the tectonic, which form belts toward south - west, northeast and west, east direction also old terrigenes belts.

The Veternik - Kallkan mountain ridge lies almost on a meridional direction along the border line with Macedonia, comprising entirely the mountain ridge of Lunik in the tectonic area of Mirdita. Natural borders of this mountain ridge are: Studa's field, Stebleva, Klenja in south - west also the gorge of Black Drini, in north - east it has a continuity with the mountain of Jabllanice also that of Miraka in south - west.

Natural borders of the expansion of Llanga's trough are presented by the mountain ridge of Lunik in north - west until the tectonic neck of Studa, that of Miraka from south - east till the entrance of the Dragan's gorge, whilst in south west it is widely opened on the valley of the upper stream of the Shkumbin river. A morphological importance present also the two complex fields in south - east of this mountain ridge, that of Klenja and Stebleva which are mainly modelled during the contact with the angular dissonance between the limestones and phlysch, being visibly expressed with their

\footnotetext{
${ }^{4}$ Group of Authors. (1983). Geologic map of Albania and the explanatory book Geology of Albania, Tirana

${ }^{5}$ Group of authors (1991). Physic Geography of Albania. Volume II, a publishement of Academy of Sciences PRA, pp. 191 - 206, Tirana
} 
sizes and morphological features. The general length of Okshtun trough between the canyon of Borova in south and estuarine at Bulqiza's shingle from north reaches about $20 \mathrm{~km}$, whilst the bed's slope is about $20 \mathrm{~m} / \mathrm{km}$ possessing a big eroding power, also from its terrigenes composition.

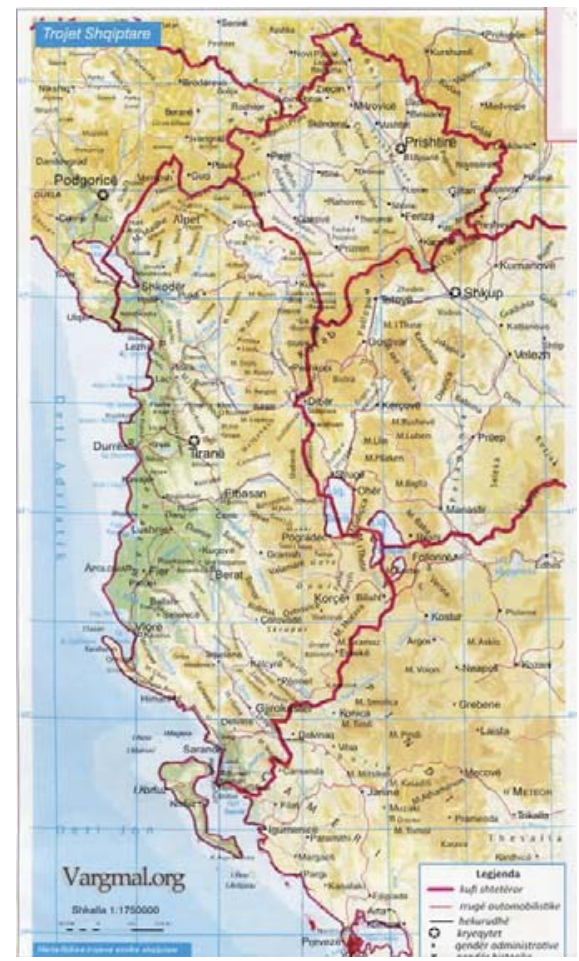

\section{References}

Aliaj, Sh. (2012). Neotectonics of Albania, Monography, Tirana

Bollobani, (Dodoveci), E. "General physical - geographical characteristics of Çermenike - Golloborde - Martanesh highlands", in: Academic Journal of Interdisciplinary Studies, No. 3/2013, pp. 343 - 350, Romë

Geoff, P. \& Jon, F. (1985). Rivers and landscape, London

Gruda, Gj. "Morphologic picularities of crasps and tectonic fractions in Albania in: Geographic Studies, No. 8/1996, pp. 33 - 35, Tirana

Gruda, Gj. (2003). Geomorphology, Monography, Tirana

Gruda, Gj. "Structural - erosive relieves", in: Geographic Studies, No. 5/1994, pp. 48 - 70, Tirana

Group of Authors. (1983). Geologic map of Albania and the explanatory book Geology of Albania, Tirana

Group of authors (1991). Physic Geography of Albania. Volume II, a publishement of Academy of Sciences PRA, pp. 191 - 206, Tirana.

Kote, Dh. \& Vranai, A. "Conglomerate thickness of Klenjë - Studë", in the Bulletin of USHT, a Series of Natural Sciences, No. 1/1965, pp. 111 - 123, Tirana

Krutaj, F. "Some picularities of Golloborda carst", in: Geographic Studies, No. 17/2006, pp. 126 - 132, Tirana

Lila, A. "The highland of Golloborda - problems linked to the evaluation of geographical position and its natural resources, in: Geographic Studies, No. 17/2006, pp. 121 - 125, Tirane

Lila, A. "Crossborder Region of Golloborda and the perspectives that the free trade development opens", in: Albanological Studies No. IV/2009, pp. 82 - 89, Tirane

Mcknight, T. (1994). Physical geography, New Jersey

Qirjazi, P., Kristo, V., Gruda, Gj. " The basic geomorphologic features of Albania and some problems of practice", in: Geographic Studies, No.2/1987, pp. $39-50$, Tirana 